\title{
The comparison of Islamic banks performance in Indonesia before and after the Action to Defend Islam event
}

\author{
Luksi Visita ${ }^{1}$
}

${ }^{1}$ Faculty of Islamic Economics and Business, UIN Walisongo Semarang, Indonesia

\begin{abstract}
Purpose - This study aims to compare the performance of Islamic banking before and after the Islamic defense action. The action to defend Islam is a manifestation of populism, which resulted in mixed responses.

Method - Financial performance consisting of return on assets (ROA), financing to deposit ratio (FDR), third party funds (DPK), non performing financing (NPF) and profit sharing financing on total financing were analyzed from 30 Islamic commercial banks and Sharia business units in Indonesia. The data were analyzed using different test paired sample T-test.
\end{abstract}

Result - The results show that only TPF and FDR have significant differences. The DPK value increases, while the FDR decreases.

Implication - This study can support industry to consider aspects needed to be taken care of during political events.

Originality - This study enriches the empirical study of political and business interaction. 


\section{Introduction}

Interaction between business and politics is an interesting study to discuss. It is an extra task to examine the interaction between business and politics in a more colorful and profound way

JIEMB | 50 for academics. In 1959, Robert Dahl, a professor of political science at Yale University, once outlined his concern and criticism of the lack of research examining the interaction between business and politics. According to Dahl (1959), the majority of studies on business-politics conducted by political science scholars have similar tone of issues, namely on government regulation, control, administration, party affairs, and propaganda.

The same point was expressed by Vogel (1966). He believes that research on business and political interactions is increasing, but its potential has not been fully explored. Vogel added that there are several topics needed to be thoroughly studied, including the power of business, political business activities, campaign funding, and representation of groups with interests.

Wilson (1985) was one of the few academics who have questioned the interaction of politics and business. Some of the things getting his concern are the efficiency of the relationship between government and politics. Another concern is the distribution of power in political and government interactions, as well as in business. Some argue that sometimes business has excessive power, so the question arising is whether the state should follow the dictates of capital (business). In fact, it is difficult to prove the opinion of the interaction between politics and business, but there are also suggestions to consider the culture and condition of society when connecting politics and business.

Naturally, if the business owner does not feel confident in the condition of a country, the investment will not be made. However, sometimes the reality is just the opposite. The state ideology and political actors present in the government have the potential to influence how business dynamics work.

Situmorang (2009) examines the interaction between politics and business. In his article entitled "Some Relationships Between Politics and Business", Situmorang opened with an illustration of business and politics in need of each other. Business is considered as a unit or organization that is dynamic in nature and can be influenced by environmental conditions. One of the environments 
referred to is the political environment, from politics of security to politics of law. In his article, Situmorang revealed that political stability is an important determinant of investment.

If we examine the latest research trends in 2019 on political and business interactions in Indonesia (Table 1), it can be seen that there are quite a number of studies examining the relationship between politics and the economy and/or business. Of the several studies on the interaction of Indonesian politics and business, there is one study that examines the effect of the Islamic Defense Action on the reaction of the Islamic capital market.

Table 1. Recent researches that examine political and business interaction

\begin{tabular}{|c|c|c|}
\hline No & $\begin{array}{l}\text { Authors \& year of } \\
\text { publication }\end{array}$ & Title \\
\hline 1. & Putra (2019) & $\begin{array}{l}\text { Political CSR communication: building reputation, ethics, and } \\
\text { aesthetics of political PR }\end{array}$ \\
\hline 2. & $\begin{array}{l}\text { Lestari, Pratomo, } \\
\text { Asalam (2019) }\end{array}$ & $\begin{array}{l}\text { The influence of political connections and capital intensity } \\
\text { on tax aggressiveness }\end{array}$ \\
\hline 3. & Aji \& Adnan (2020) & $\begin{array}{l}\text { Business and political relations: a study of the role of the } \\
\text { "Dewi Sri" family in influencing the policies of the Brebes } \\
\text { Regency government } 2017-2022\end{array}$ \\
\hline 4. & Faudhiah (2019) & $\begin{array}{l}\text { Political oligarchy: meeting of business interests and political } \\
\text { interests in Nagan Raya }\end{array}$ \\
\hline 5. & $\begin{array}{l}\text { Munawaro \& Ramdany } \\
\text { (2019) }\end{array}$ & $\begin{array}{l}\text { The role of CSR, company size, executives' character, and } \\
\text { political connections to potential tax avoidance }\end{array}$ \\
\hline 6. & Kartiasih (2019) & Inflation and the political business cycle in Indonesia \\
\hline 7. & Febriyanti (2019) & $\begin{array}{l}\text { Go-Jek's political risk assessment in expanding business } \\
\text { abroad (Vietnam and the Philippines) in } 2018\end{array}$ \\
\hline 8. & Wahyuono (2019) & $\begin{array}{l}\text { The political economy of local game developers: } \\
\text { spatialization and business expansion of PT Git Solution and } \\
\text { Noodzilla in Yogyakarta }\end{array}$ \\
\hline 9. & Putra (2019) & $\begin{array}{l}\text { Influence of corporate risk, political connections, and } \\
\text { leverage against tax avoidance in companies listed on the } \\
\text { IDX }\end{array}$ \\
\hline 10. & Khamim \& Sabri (2019) & $\begin{array}{l}\text { Media conglomerates and political parties: reading the MNC } \\
\text { group's relationship with the Perindo party }\end{array}$ \\
\hline 11. & Arianto (2019) & $\begin{array}{l}\text { Political buzzer contestation in guarding the DKI Jakarta } \\
\text { Regional Budget }\end{array}$ \\
\hline 12. & Armadiyanti (2019) & $\begin{array}{l}\text { Connection between company politics and decisions about } \\
\text { choosing auditors with earnings management as a } \\
\text { moderating variable }\end{array}$ \\
\hline 13. & Maarif (2019) & $\begin{array}{l}\text { Privatization of BUMN and reorientation of the role of the } \\
\text { state in the business sector after new orders (comparative } \\
\text { study of three reigns) }\end{array}$ \\
\hline 14. & $\begin{array}{l}\text { Pranoto \& Widagdo } \\
\text { (2016) }\end{array}$ & $\begin{array}{l}\text { The influence of political connections and corporate } \\
\text { governance on aggressiveness tax }\end{array}$ \\
\hline
\end{tabular}


Fauzi and Ichsan (2018) found that there was an increasing trend of Islamic stock transactions after the action. Even so, there is no research in Indonesia specifically addressing the issue of populism as a potential phenomenon to influence the performance of Islamic financial institutions.

Indonesia had carried out the presidential general election and legislative general election simultaneously in May 2019. Like political rivalry in general, the 2019 Indonesian general elections were also filled with various political efforts and maneuvers by parties with interests. From the five to ten years of political rivalry, there has been a high intensity of polarization in the 2019 simultaneous elections, and this is strongly related to the phenomenon of Islamic populism (Margiansyah, 2019).

The resurgence of the intensity of Islamic populism in the pre2019 simultaneous elections has begun to appear earlier in the 2014 election and the 2017 DKI gubernatorial election. The election followed by two governor candidates in the 2017 DKI gubernatorial election was marked by accusations of religious blasphemy, civil unrest, strong political identity, and religious campaign efforts selling fear (religious fear-mongering). Furthermore, in the period of political rivalry, there were political social media discourses from interested parties which resulted in segregation within the society.

What happened in the 2017 DKI regional election also occured in the 2019 political rivalry. As stated by the senior researcher from the Australian National University, Tapsell (2019), that the polarization emerging in the 2014 election and the 2017 DKI gubernatorial election was passed on to the 2019 election. The 2019 election was filled with hoax war and utterances of hate, black campaign and political propaganda (Susanti, Setiajid, \& Wardhani, 2018; Susanto, 2014).

The 2014-2019 political rivalry which is filled with politics of identity in Indonesia can be interpreted as the instability of political conditions and has potential risks to companies in Indonesia in general. The politics of identity occurring resulted in the polarization between the "religious" and the "nationalist" camps which was very strong and finally reached its peak in the 2019 elections (Nurjaman, 2017).

Although the phenomenon of Islamic populism emerged in the 2014-2019 political rivalry, based on researchers' observations, 
conceptual studies that examine the impact of populism on industry, business and the economy are still limited. To accommodate the lack of studies linking populism and business, researchers will examine differences in the performance of Islamic banking in Indonesia before and after Islamic populism. In the context of this research, the phenomenon of Islamic populism is marked by "Action to Defend Islam".

Indonesia's inflation rate increased during the months of 20142019 political rivalry. It indicates that there are risks faced by industries and companies in Indonesia during this political rivalry. However, the plot twist is the alleged significant positive relationship between politics of identity and people's choice to choose Islamic banking.

As an initial assumption, the researcher predicts that politics of identity based on religion will influence people's consumerism choices, especially for people who are sensitive to the sharia or Islamic branding label of the product they use. Therefore, although Islamic populism in the 2014-2019 political rivalry has potential risks for companies, researchers predict a blessing in disguise for the sharia industry in Indonesia.

Apart from the lack of studies discussing political and economic interactions, this study is an empirical effort aiming to provide new insights into the behavior of the business sector during the occurrence of populism.

To be more specific, the idea that political conditions and political security have a strong influence on the economy have often been echoed by academics. However, there has been no clear conclusion from academics about which conditions of the political security are referred to. This study is expected to be one of the studies that can help future researchers to examine more specifically, which political conditions have the potential to harm the economy and which tend not to have a significant impact on the economy.

Based on the description of the research needs above, the researcher conducted a quantitative study of the performance of Islamic banking during the amplification of Islamic populism as represented by the Action to Defend Islam in 2016. To examine these objectives, researchers use the theory of Planned Behavior 
framework, collectivism theory, and theory of social identity as the main basis of the research.

\section{Literature review}

\section{The Action to Defend Islam}

This action is a demonstration initiated by the National Movement for Fatwa Guards of the Indonesian Ulema Council (GNPF-MUI), consisting of seven waves within seven months from 14 October 2016 to 5 May 2017.

The Action to Defend Islam was a response to the legal process of the Governor of DKI Jakarta at that time, Basuki Tjahja Purnama (BTP). Reported by BBC Indonesia news, on September 27, 2016, BTP visited Pramuka Island in the Kepulauan Seribu and delivered a speech related to the grouper farming empowerment program. On October 6, 2016, Buni Yani, a netizen, uploaded a material entitled "Blasphemy Against Religion?" and quoted the video of Basuki Tjahja Purnama's speech. This video went viral and sparked negative reactions from several Muslim communities. In the end, several Islamic organizations reported BTP to the police.

The Action to Defend Islam consisted of seven waves from October $14^{\text {th }}, 2016$ up to May $3^{\text {rd }}, 2017$. There are various analysis related to the Action to Defend Islam. Several political observers and academics considered that the BTP report imposed political elements. As for academics and observers of religious organizations, they also considered the involvement of several religious authorities as a form of fragmentation emerging before the action (Burhan, 2016). Irfan Prayogi, in his article, considered that during the Action to Defend Islam, political identity was formed, and this collective awareness became one of the determinants on the victory of the newcomers in the 2017 DKI Jakarta Governor election contest. Riadi and Drajat (2019) explained their analysis that mass media framing played a role in the formation of the collective identity of the Muslim community. It is believed that the GNPF MUI decision within the Action to Defend Islam is beyond the capacity of religious organizations and should have not be influenced by politics.

The Indonesian mass media also have different analyses of the Action to Defend Islam. Pradipta et al. (2018) analyzed two mass media creating contrasting news frames about the Action to Defend Islam, namely the BBC and Republika. BBC is considered to form 
action news with a tone that tends to be connotative. While Fauzi (2019) analyzed the news in Tabloid Media People and found that there is propaganda nuance.

\section{Islamic populism}

Action to Defend Islam is considered to be a manifestation of Islamic populism. In the past, populism often emerged from left-wing politics, but nowadays this is not always the case. Mouffee (2005) in his book entitled "The 'End of Politics' and the Challenge of RightWing Populism" reveals that during the past 10 years, populism emerged through resistance movements on right-wing politics.

Mudde and Kaltwasser (2017) in their book entitled "Populist: A Very Short Introduction" revealed a definition of populism that is often referred to by researchers. Populism can be interpreted as an ideology that divides society into two groups; the "holy groups" and the "corrupt elites," with the principle that politics is an expression that must be based on the will of the people.

Petty (2017) describes the origins of populism in an article entitled "Fascinating History of Populism" which was published online by Aeon. Based on her timeline, populism was born in the Cold War era, where historian Hofstadter criticized the Populist Party. She also added that populism used to be a term that could unite the workforce, but now it refers to something that separates the middle class.

The narrative of populism is actually not new and is often echoed in Indonesian political rivalry. According to the timeline, populism in Indonesia in the era of colonialism was more dominated by nationalist populism, although there was also Islamic populism at that time. Islamic populism was raised by Hadiz (2014) and described movements such as populism, but with Islam as a group identity. Islamic populism is a form of resistance to injustice because Islam possesses and sets the stage for expressions of resistance to injustice.

Research on Islamic populism in Indonesia was also conducted by Jati (2013) who analyzed radical movements in Indonesia from the perspective of Islamic populism. According to his research, radicalism is not always perceived as a form of violence and terrorism but can also take the form of aggressive efforts against authoritarian regimes. The form of aggressive resistance can be manifested by implementing the concept of sharia and the desire for 
a caliphate. These efforts are considered by the radicalism movement as a way to fight economic inequality and political marginalization of Muslims.

In a more global scope, there are several researchers who JIEMB | 56 study Islamic populism. Salamey and Pearson (2007) examined the existence of Hezbollah in Lebanon as a symbol of resistance to western capitalism. Both also added that economic inequality and poverty are the main factors encouraging the growth of Islamic populism. Yilmaz (2018) examined how Islamic populism encourages AK PARTI (Justice and Development Party) in Turkey to carry out authoritarian, conservative, and regressive social engineering through educational institutions. Social engineering supported by Recep Tayyip Erdoğan as president, as Yilmaz mentioned, contains advocacy against anti-western views.

Based on the previously mentioned description of the literature review, as the researcher trying to relate the study, the Islamic populism movement is considered to provide space for the growth and development of the Islamic sector in Indonesia. This is because since colonialism the Islamic populism movement has attempted to advocate for the development of sharia commitments in Indonesia. Therefore, it makes sense that during the mass mobilization in the name of religion, there is an increase of attention of the people towards the sharia industry.

\section{Organizational performance of sharia banks}

Performance is a common and favorite topic in business, management and organizational studies. The factors influencing organizational performance can be seen from various forms of perspectives, theories, and frameworks of thinking in the field of business and management. For example, in strategic management studies, organizational performance is often associated with innovation, strategic planning, resource management strategies, and ambidexterity. In the field of human resource management, work roles, organizational commitment, organizational culture, organizational configuration have a separate role in organizational performance.

Although the way to measure performance is rather various, the measurement of company performance most often used by Indonesian researchers is financial performance. This is understandable because financial performance is generally 
measured quantitatively and through financial reports that are more accessible than other performance measurements.

\section{Theory of planned behavior}

This study used the Theory of Planned Behavior (TPB) because it can provide an explanation of the factors driving someone to do something. TPB was proposed by Icek Ajzen in 1985. Icek Ajzen is a professor emeritus from the University of Massachusetts Amherst. This theory is a further development of the previous theory, namely the Theory of Reasoned Action written by the same author.

The fundamental factor of TPB is the individual's intention to perform certain behaviors. Intention is interpreted as a motivational factor that affects behavior. Intentions can take the form of, among others; how hard a person tries, how many plans are made to pursue certain targets, and so on. According to this theory, the stronger the intention to engage in a behavior, the more likely the person does what was intended.

According to the TPB framework, a person's intention to do something is influenced by behavior, subjective norms, and perceived behavioral control. Of the three antecedents, the subjective norm factor is the most appropriate to describe the relationship between the phenomenon of Islamic populism and the Islamic banking sector, which is expected to benefit. Normative beliefs relate to the possibility that an important individual or group of referrers approves or disapproves of certain behaviors. This occurs in a collective form, for example, when preparing for an action, when there is a battle of opinion in cyberspace about the action, and other collective activities.

Antecedents of subjective norms are interpreted as social pressure felt by an individual, so that the individual will do something according to what is expected or predicted by those around him. Religion is not only a form of expression of an individual's spirituality, but also carries a social construct and is a form of social norms. For example, the virtues of Islam are revealed and disseminated in the form of da'wah. This indicates that the determination of a Muslim's life is more or less influenced by the direction of other people. Therefore, religion in the perspective of TPB can be treated and viewed as a subjective norm that has the potential to direct one's behavior. 
Islamic populism as a phenomenon of religious collectivism and a manifestation of social identity

According to collectivism theory, everyone who is in a group feels that they have the same values and goals so that they have greater orientation and priority towards their group rather than themselves. In a group, members will exchange knowledge and skills, interact, coordinate, synergize, so that there is collective strength to achieve a certain goal.

Based on social identity theory, because of the high interaction between individuals and groups, collectivism sees the behaviors, views, and decisions taken by an individual as being potentially influenced by the group affiliated with him. For example, a person can become more motivated to shop online together with his group of friends.

Mass mobilization with religious elements is a form of collectivism culture, and has the potential to influence customer behavior towards a product. Moreover, religiosity has an important role in customer experience when buying a product. If a brand is not in line with the beliefs of a society, it is certain that the response will not be positive. The illustration is when an Islamic religious group most likely prefers products with halal labels. Another example is that Islamic societies will more easily agree to boycott products from Denmark which has a history of desecrating caricatures of the prophet Muhammad.

Associated with this research agenda, Islamic populist groups have the same values, points of views, and goals to overthrow incumbents. The difference between the "religious" and "nationalist" camps is high, giving rise to the understanding that populist groups are groups that are always close to religious attributes and bring out religiously laden messages to both their own group and the surrounding community. One of the agendas of rightwing Islamic populists since the colonialism era has been to revive their own businesses and advocates for the application of the sharia concept in Indonesia.

People who witness and pay attention to mass mobilizations, their agendas and messages, have the potential to be influenced to believe in the principles they have, especially Muslim societies that are not part of the mass mobilization. The similarity of religion that is shared by the populist masses of Islam and outside of that group 
brings the potential of a feeling of being part of mass mobilization, so that Muslims in general will have a higher attention to the sharia industry advocated by right-wing populists. High attention to Islamic banking will have the potential to an increased popularity and in the end can provide a way for Islamic banks to increase their profits. Therefore, based on the description above, the hypothesis proposed is:

There is a significant difference in the performance of Islamic banks in Indonesia before and after the Action to Defend Islam event

\section{Methodology}

This study uses a quantitative approach. Research with a quantitative approach emphasizes on hypothesis testing. More specifically, the analytical method used in this study is a different test. This study uses secondary data obtained from the official website of Islamic banks in Indonesia as well as from government agencies responsible for overseeing Islamic banks in Indonesia, such as the OJK. The quantitative data comes from financial reports, namely balance sheets and profit and loss statements of several Islamic banks.

Samples to be examined in this study are Islamic Commercial Banks and Sharia Business Units. The later were also included in this study because the number of Indonesian Sharia Commercial Banks was deemed too small to obtain valid and reliable quantitative analysis results. In total there were 15 Islamic commercial banks operating in Indonesia during the observation period of this study (September 2016 - December 2016). Meanwhile, there were a total of 20 Sharia Business Units actively operating in Indonesia during the research observation period. In this study, researchers analyzed a total of 30 companies. The remaining companies that were not included in the sample of this study were because they did not have financial reports that could be accessed during the research observation period.

The data collection in this study was carried out using documentation techniques by collecting and searching for secondary data. The data used are quarterly financial reports and bank profile analyses taken from the official website.

To test the hypothesis in this study, two different test analyzes were used. The stages of testing are: 1) Identifying the period of the Journal of Islamic Economics, Management, and Business-Vol 2. No.1 (2020 
Islamic populism phenomenon represented by the Action to Defend Islam; 2) Conducting validity checking by interviewing related parties; 3) Concluding whether there are significant differences between the performance ratios specified in this study before and after the event occurred. The technical analysis used in this research is descriptive analysis and analysis of the two difference test means. Analysis of the mean difference test was carried out through the T-test difference test with related samples. This technique is used because the researchers intended to test the average of two related samples, where the sample remains from the same company, with the different conditions that is before and after the Action to Defend Islam event.

The different test steps are:

Determination of the hypothesis

Ho: $\mu_{1} \neq \mu_{2}$, which means that the average financial performance of Islamic banks in Indonesia before and after the Action to Defend Islam is different.

Ho: $\mu_{1}=\mu_{2}$, which means that the average financial performance of Islamic banks in Indonesia before and after the Islamic Defense Action is the same or there is no significant difference.

The significant level used is $\alpha=5 \%$ and the confidence level is $95 \%$. If the $p$ value of the paired sample test is less than 0.05 , then $\mathrm{Ho}$ is accepted and if the $\mathrm{p}$ value is more than 0.05 , then Ho is rejected.

\section{Operationalization of variables}

\section{Islamic populism}

Populism in this study is an event of Action to Defend Islam which occurred during seven waves. Action to Defend Islam event is an action that is considered to have sparked the rise of the Islamic political movement in Indonesia and gave a deep impression on the Indonesian people in general. Even though the Action to Defend Islam event occurred in seven waves, this study focused on the Action to Defend Islam event I - III because two major Indonesian Islamic organizations (Nahdatul Ulama and Muhammadiyah) chose not to be involved in the following waves. The absence of support from these two organizations can indicate that the Action to Defend Islam event in the fourth movement after the previous three does 
not adequately represent the phenomenon of Islamic populism. The details of the events timeline are:

The Action to Defend Islam I occurred on October 14, 2016

The Action to Defend Islam II occurred on November 4, 2016

The Action to Defend Islam III occurred on December 2, 2016

\section{Company performance}

This research used the measurement of return on assets (ROA), financing to deposit ratio (FDR), third party funds (DPK)s coupled with non-performing financing (NPF) and profit sharing financing to total financing (Saekhu, 2017). These four ratios were chosen because they can measure the level of funds provided by customers. The four ratios are obtained from the financial statements.

\section{Results and discussion}

After getting the data rate and value of Islamic banking performance, the next step is to do descriptive analysis and test the difference. Table 2 presents the results of the descriptive analysis. Conclusion on the outline of the performance of Islamic banking before and after the action can be obtained. The means of almost all performance measurements in this study has increased from before and after action, except for FDR.

There was an increase in the average value of third party funds from the time before the action and after the action, from Rp. 8580121.80 million to IDR 9076316.1. The NPF ratio increased from 5.06 to 5.25 . ROA ratio increased from 1.48 to 1.53 . The ratio of

Table 2. Results of descriptive analysis

\begin{tabular}{llllll}
\hline \multicolumn{5}{c}{ Paired Samples Statistics } \\
\hline Pair 1 & DPK1 & 8580121.80 & 30 & 14123462.524 & 2578579.671 \\
& DPK2 & 9076316.10 & 30 & 14731140.618 & 2689526.005 \\
Pair 2 & NPF1 & 5.0653 & 30 & 6.22365 & 1.13628 \\
& NPF2 & 5.2557 & 30 & 8.33635 & 1.52200 \\
Pair 3 & ROA1 & 1.4813 & 30 & 3.71930 & .67905 \\
& ROA2 & 1.5317 & 30 & 3.58026 & .65366 \\
Pair 4 & PBHTP1 & 31.4553 & 30 & 23.13479 & 4.22382 \\
& PBHTP2 & 32.7070 & 30 & 24.01745 & 4.38497 \\
Pair 5 & FDR1 & 111.4450 & 30 & 47.36727 & 8.64804 \\
& FDR2 & 101.0427 & 30 & 33.31704 & 6.08283 \\
\hline
\end{tabular}


Table 3. Results of the analysis of different test for TPF, NPF, ROA, PBH/TP, and FDR

\begin{tabular}{llllll}
\hline & Mean & $\begin{array}{l}\text { Std. } \\
\text { Deviation }\end{array}$ & $\begin{array}{l}\text { Std. Error } \\
\text { Mean }\end{array}$ & T & $\begin{array}{l}\text { Sig. } \\
\text { (2-tailed) }\end{array}$ \\
\hline DPK1 - DPK2 & -496.194 .300 & 963.070 .360 & 175.831 .787 & $-2,822$ & 0,009 \\
NPF1 - NPF2 & $-0,19033$ & 309,855 & 0,56572 & $-0,336$ & 0,739 \\
ROA1 - ROA2 & $-0,05033$ & 176,940 & 0,32305 & $-0,156$ & 0,877 \\
PBHTP1 - PBHTP2 & $-125,16$ & 547,406 & 0,99942 & 1,25 & $-125,17$ \\
FDR1 - FDR2 & 1,040 & 2,031 & 370,96 & 2,80 & 0,009 \\
\hline
\end{tabular}

profit sharing/total financing increased from 31.45 to 32.7 . Finally, the FDR ratio is the only performance that has decreased from 111.44 to 101.04 .

Table 3 presents the results of the analysis of different tests. Of the total five performance variables used, only TPF and FDR have a $p$ value below 0.05 (TPF $=0.09 ; F D R=0.09)$. This indicates that only TPF and FDR have significant differences before and after the action. Especially for FDR, the difference is indicated by a decrease in value.

NPF, ROA, and PBH/TP have an added value, but not significant. This insignificant result may be due to NPF, ROA, and $\mathrm{PBH} / \mathrm{TP}$ not being the sensitive variables to increase the number of customers. In contrast to TPF which interacts directly and can represent an increase in customers, the FDR which decreased significantly between before and after the action meant that not much financing was provided by banks or requested by consumers.

With these results, it can be concluded that the proposed hypothesis is partially supported because not all performance measurements have changed significantly before and after the action.

\section{Conclusion}

From this study, it can be concluded that there are significant differences from third party funds managed by Islamic banks before and after the action. It means; first, the number of Islamic bank customers increased after the action. Second, this significant difference in third party funds could also mean that the number of customers did not increase significantly, but instead there were additional funds coming from customer accounts. These two meanings indicate that the collectivism action of Muslims has the potential to be one of the factors influencing the increase in the 
volume of third party funds. Even so, further research is needed to ensure that this volume increase is due to the action of Muslims and not due to other factors.

\section{Reference}

Aji, J. A. K., \& Adnan, M. (2020). Relasi Bisnis dan Politik: Studi Peran Keluarga "Dewi Sri" Dalam Memengaruhi Kebijakan Pemerintah Kabupaten Brebes 2017-2022. Journal of Politic and Government Studies, 9(03), 71-80.

Ajzen, I. (1991). The theory of planned behavior. Organizational behavior and human decision processes. 50.

Arianto, B. (2019). Kontestasi Buzzer Politik dalam Mengawal APBD DKI Jakarta. Jurnal Polinter: Kajian Politik dan Hubungan Internasional, 5(1), 54-74.

Armadiyanti, P. (2019). Koneksi politik perusahaan dan keputusan pemilihan auditor dengan manajemen laba sebagai variabel moderasi. (Doctoral dissertation, Universitas Airlangga).

Faudhiah, D. (2019). Oligarki Politik: Pertemuan Kepentingan Bisnis dan Kepentingan Politik Di Nagan Raya (Doctoral dissertation, UIN ArRaniry Banda Aceh).

Fauzi, R. (2019). Analisis pemberitaan aksi bela islam di tabloid media umat (analisis framing dari segi dakwah terhadap aksi bela islam di tabloid media umat edisi desember tahun 2016. Syntax, 1(4).

Fauzi, M. A., \& Ichsan, N. (2018). Reaksi Pasar Modal Syariah Terhadap Aksi Bela Islam 212 di Jakarta. SOSIO DIALEKTIKA, 3(1).

Febriyanti, H. (2019). Asesmen risiko politik go-jek dalam perluasan bisnis ke luar negeri (vietnam dan filipina) pada tahun 2018 (Doctoral dissertation, Universitas Bakrie).

Hadiz, V. R. (2014). A new Islamic populism and the contradictions of development. Journal of Contemporary Asia, 44(1), 125-143.

Jati, W. R. (2013). Radicalism in the perspective of Islamic-populism: trajectory of political Islam in Indonesia. Journal of Indonesian Islam, 7(2), 268-287.

Kartiasih, F. (2019). Inflasi dan Siklus Bisnis Politik di Indonesia. Media Trend, 14(2), 219-228.

Khamim, A. B. M., \& Sabri, M. F. (2019). Konglomerasi Media dan Partai Politik: Membaca Relasi MNC Group dengan Partai Perindo. Politika: Jurnal IImu Politik, 10(2), 112-136. 
Lestari, P. A. S., Pratomo, D., \& Asalam, A. G. (2019). Pengaruh Koneksi Politik dan Capital Intensity Terhadap Agresivitas Pajak. Jurnal ASET (Akuntansi Riset), 11(1), 41-54.

Ma'arif, S. (2019). Privatisasi BUMN dan Reorientasi Peran Negara di Sektor Bisnis Orde Baru. Jurnal Analisis Sosial Politik, 3(1).

Margiansyah, D. (2019). Populism in Contemporary Indonesia: The Transformation of Competitive Populism and Its Consequences in the Dynamics of Political Contestations Ahead of the 2019 Election. Journal of Political Research, 16(1), 47-68.

Mouffe, C. (2005). The 'end of politics' and the challenge of right-wing populism. Populism and the Mirror of Democracy, 50, 155.

Mudde, C., \& Kaltwasser, C. R. (2017). Populism: A very short introduction. Oxford University Press.

Munawaro, M. A., \& Ramdany, R. (2019). Peran CSR, Ukuran Perusahaan, Karakter Eksekutif dan Koneksi Politik Terhadap Potensi Tax avoidance. Jurnal Akuntansi, 8(2), 109-121.

Nurjaman, A. (2017). Religious Cleavage at the Local Level, Indonesia: Party Identification Without Electoral Commitment. Journal of social politics, 3(2).

Petty, A. (2017, August 07). The fascinating history of populism.

Retrieved April 15, 2020, from

https://theweek.com/articles/715485/fascinating-history-populism

Pradipta, A. L., Hidayah, N. W. N., Haya, A. N. A., Ervania, C., \& Kristanto, D. (2018). Analisis Bingkai Pemberitaan Aksi Bela Islam 2 Desember 2016 (Aksi 212) Di Media Massa Bbc (Indonesia) \& Republika. dalam Jurnal Informasi: Kajian IImu Komunikasi, 48(1).

Pranoto, B. A., \& Widagdo, A. K. (2016). Pengaruh Koneksi Politik dan Corporate Governance Terhadap Tax Aggressiveness.

Putra, D. K. S. (2019). Komunikasi CSR politik: membangun reputasi, etika, dan estetika PR politik. Prenada Media.

Putra, R. W. S. (2019). Pengaruh Corporate Risk, Koneksi Politik Dan Leverage Terhadap Tax Avoidance Pada Perusahaan Yang Terdaftar Di Bei (Doctoral dissertation, STIE Perbanas Surabaya).

Riadi, B., \& Drajat, D. (2019). Analisis Framing Gerakan Sosial: Studi Pada Gerakan Aksi Bela Islam 212. Holistik, 3(1), 10-18.

Saekhu, S. (2017). Dampak Indikator Makro Ekonomi terhadap Dana Pihak Ketiga Perbankan Syariah. Economica: Jurnal Ekonomi Islam, 8(1), 103-130.

Salamey, I., \& Pearson, F. (2007). Hezbollah: a proletarian party with an Islamic manifesto-a sociopolitical analysis of Islamist populism in 
Lebanon and the Middle East. Small Wars \& Insurgencies, 18(3), 416-438.

Situmorang, J. R. (2009). Beberapa Keterkaitan Antara Politik dan Bisnis. Jurnal Administrasi Bisnis, 5(2).

Susanti, M. H., Setiajid, S., \& Wardhani, N. W. (2018). Kampanye Pemilu 2019 Dan Potensi Ancaman Disintegrasi Bangsa. In Seminar Nasional PKn UNNES (Vol. 2, No. 1, pp. 199-204).

Tapsell, R. (22 March 2019). The Polarisation Paradox in Indonesia's 2019 Elections. New Mandala, retrieved from: https://www.newmandala.org/the-polarisation-paradox-inindonesias-2019-elections/

Wahyuono, J. A. (2019). Ekonomi politik pengembang game lokal: Spasialisasi dan Ekspansi Bisnis PT Git Solution dan Noobzilla di Yogyakarta. Journal Communication Spectrum: Capturing New Perspectives in Communication, 9(2), 125-142.

Wilson, G. K. (1985). Business and politics: A comparative introduction. Macmillan International Higher Education.

Yilmaz, I. (2018). Islamic populism and creating desirable citizens in erdogan's new turkey. Mediterranean Quarterly, 29(4), 52-76. 
Luksi Visita

JIEMB | 66

Journal of Islamic Economics, Management, and Business-Vol 2. No.1 (2020 